\title{
The Effectiveness of Interactive Multimedia in Learning Indonesian Language Skills in Higher Education
}

\author{
Biya Ebi Praheto, Andayani, Muhammad Rohmadi, Nugraheni Eko Wardani \\ Sebelas Maret University of Surakarta, Indonesia. Email: biya.ebi@ustjogja.ac.id
}

\begin{abstract}
Computer-based media such as interactive multimedia plays an important role in learning Indonesian language skills. The objective of this research is to determine the effectiveness of interactive multimedia in learning Indonesian language skills in higher education. This experimental research used the port-test along with a control group design. The population of this research was the second semester students of the Elementary School Education Study Program at four higher education institutions. To determine the experimental class, the random sampling technique was used considerably. IKIP PGRI Wates is an experimental class through which interactive multimedia is compared to three control groups namely Slamet Riyadi University of Surakarta using video subscription media, Tunas Pembangunan Surakarta University applying media prize, and Ahmad Dahlan University of Yogyakarta using the powerpoint media. The data on Indonesian language skills tests include tests of listening, speaking, reading and writing abilities. The data were then analyzed using the one-way ANOVA. The results show that the application of interactive multimedia is effectively used in learning language language skills compared to learning using other media. In addition, interactive multimedia can also be applied to study independently outside the classroom.
\end{abstract}

Keywords: Interactive Multimedia, Indonesian Language Skills, Listening Skills, Speaking Skills, Reading Skills, Writing Skills

\section{Introduction}

Indonesian language plays a pivotal role in the educational world of Indonesia. As a language of instruction in education, Indonesian language is one of the mandatory lessons that must be taught in educational units as stated in the Government Regulation of the Republic of Indonesia Number 57/2014 concerning the development and protection of language and literature. In terms of the improvement of Indonesian language function, Article 18 Paragraph 1 states that units of basic education, secondary education, higher education, and equality education program must use Indonesian language in administering teaching and learning activities. In higher education almost all study programs hold general courses in Indonesian language. This is because Indonesian language is a language of instruction in learning and is used by students to communicate both verbally and non-verbally.

In general, Indonesian language learning at tertiary institutions relates to writing, spelling, and language skills or abilities, and the use of language in the scientific work. However, the Elementary School Teacher Education Study Program emphasizes the mastery of Indonesian language skills that will be useful for students when teaching in primary schools in the future. The obstacles in learning Indonesian language in higher education particularly in the Primary School Teacher Education Study Program are almost the same with learning situations in schools.

(C) AesthetixMS 2020. This Open Access article is published under a Creative Commons Attribution Non-Commercial 4.0 International License (http://creativecommons.org/licenses/by-nc/4.0/), which permits non-commercial re-use, distribution, and reproduction in any medium, provided the original work is properly cited. For citation use the DOI. For commercial re-use, please contact editor@rupkatha.com. 
Monotonous learning does not actively involve students resulting in an unattractive classroom atmosphere. In addition, lecturers merely use powerpoint media when teaching, and students take notes, or present materials in groups. This gamut of learning is not interactive. The same thing happens in the learning of Indonesian language skills namely listening, speaking, reading and writing.

Observations in several universities show that lecturers do not use interactive media in learning. Lecturers only use powerpoint when teaching. In addition, the media display is full of text-based materials. As a consequence, students get bored in learning. Students' boredom makes learning ineffective and the materials cannot be learned properly. In addition, learning Indonesian language skills not only requires the mastery of materials, but also promotes learning practices intensively. The mastery of Indonesian language skills is crucial for students to generate communicative competence ahead of likelihood to be prospective elementary school teachers.

Problems in the Elementary School Teacher Education Study Program (PGSD) is mainly concerned with the learning mastery of Indonesian language skills. Many students find it difficult to learn Indonesian language resulting in low grades. Pu'at (2017: 108) highlights that the average grade of students' daily tests at SD Negeri 11 Tebat Karai, Kepahiang Regency, Bengkulu Province only reached 50.0o. Ahmad's research (2017: 76) in class IVA of SD Negeri o1 Metro Pusat emphasizes that students' grades of Indonesian language lessons are very low, for example, more than $50 \%$ of students are incomplete due to their low reading ability. Lakilaf and Suarjana (2017: 285) point out that the second grade students' achievement in writing at SD Negeri 3 Banjar Jawa cannot reach the average score of 75 . In fact, the students' average score reaches 65 , so that only 27\% of students meet the Minimum Mastery Criteria (KKM). Furthermore, Zuhari, et al., (2018: 12) in their research at one of the elementary schools in Bandung City report that many students find difficulties in understanding the contents of reading materials, for example, 33 students (69.70\%) in class IV experience deficiencies in comprehension reading skills. Wicaksono, et al., (2019: 308) mention that the fourth grade students at SDN Purwantoro 2 Malang find difficulties in writing poetry.

The problems in primary schools will be directly proportional to indicate the Indonesian language learning in the Elementary School Teacher Education (PGSD) Study Program. This is because elementary school teachers are skillful speaking Indonesian language in terms of listening, speaking, reading and writing aspects, so that learning Indonesian language skills in the Elementary School Teacher Education (PGSD) Study Program must encourage students to be skillful Indonesian language speakers and prospective competent elementary school teachers. Thus, innovative learning is what students need to master the materials of Indonesian language skills.

For that reason, it is necessary to have innovations in learning Indonesian language in the Elementary School Teacher Education (PGSD) Study Program especially in learning Indonesian Language Skills courses. Biya Ebi Praheto, (2019), The innovation of learning and teaching is more interactive both in terms of lecturers, students, and the media of instructions. In this regard, an adobe flash-based interactive multimedia was developed to integrate various elements into a form of interactive learning multimedia of Indonesian language skills for Elementary School Teacher Education (PGSD) Study Program students. It is hoped that this interactive multimedia can improve the quality of learning both processes and results in Indonesian language skills courses. The interactive multimedia produced from this research cannot only be used by lecturers to teach in class, but also by students to study in the classroom or outside the classroom independently. 


\section{Literature Review}

\subsection{Interactive Multimedia}

Multimedia technology evolves and changes the way people learn and access a wide variety of information (Ziden and Rahman, 2013). Munir (2012) states that multimedia is a combination of various elements in the form of images, texts, videos, graphics, animations, sounds, interactions, and so forth that have been packaged into digital (computerized) files, and used to deliver messages to the public. In addition, Reddi and Mishra (2003) suggest that interactive multimedia is defined as an integration of elements of several media (audio, video, graphics, text, animation, etc.) into a synergistic and symbiotic unity that results in more benefits for users and the elements of media can be provided individually. Mayer (2011) defines multimedia as a presentation of materials using pictures as well as words. According to Vaughan (2014), multimedia is a combination of texts, graphics, arts, sounds, animations, and videos that becomes interrelated elements. When it can adjust to the user's wishes, display multimedia projects can control what and when elements are submitted, and this is commonly called interactive multimedia. Philips (1997) mentions that interactive multimedia is a phrase that describes a new wave of computer software, especially those related to the information section. This multimedia component is characterized by the presence of texts, images, sounds, animations and videos. Some or all of its components are organized into coherent programs. The interactive component refers to the process of empowering users to control the environment using a computer. The interactive multimedia is equipped with a controller that can be operated by the users, so that they can choose what they want for the next processes (Daryanto, 2013). Multimedia teaching will enrich the teaching content and time that can be used as best as possible in the classroom, and it makes student-centered approach more fundamental in improving the classroom efficiency (Patel, 2013). Ruomei \& Feng (2012) mention that multimedia can increase the learning motivation and improve the teaching efficiency.

\subsection{Language Skills}

Language skills cover four aspects, namely listening, speaking, reading and writing. These four aspects of skills are interrelated with one another. Orsdemir and Yilmazer (2016) suggest that listening is an important component for language performance, whether learners communicate at school, at work, or in the community, and this skill is an active and complex process in which listeners must distinguish between sounds, understanding vocabularies and grammatical structures, interpreting pauses and intonations directly in the socio-cultural context of speeches. On the other hand, listening comprehension is different from the process of understanding spoken language. This includes knowing the speech sounds, understanding the meaning of individual words, and understanding sentence syntax (Gilakjani \& Sabouri, 2016).

Furthermore, Hamouda (2013) mentions that listening comprehension refers to understanding what the listener has done and heard despite the fact that he or she can repeat sounds without real understanding. On the other hand, Caspersz and Stasinska (2015) state that listening is not the same as listening attentively. While listening is a physiological process, listening attentively is a conscious process that requires listeners to be mentally mindful. Thus, speaking is one of the most important skills to develop and improve speaking competence compared to other language skills because people who know the language are usually referred to as speakers of that language. However, speaking skills are considered as one of the most difficult aspects of language learning (Leong, 2017; Tuan \& Mai, 2015). Speaking is an interactive process in 
building meanings consisting of producing and receiving information (Brown, 2015; Burns \& Joyce, 1997). Speaking can be interpreted as the ability to speak the sounds of language to express or convey thoughts, ideas or feelings verbally (Brown and Yule, 1996). Reading is an interactive process in which readers build meaningful text representations using effective reading strategies (Gilakjani and Sabouri, 2016). Crawley and Mountain (1995) mention reading as an integral part of word recognition activities, literal understanding, interpretation, critical reading and creative understanding. Reading comprehension means perceiving the vocabulary used in written texts and making connections between them to achieve a comprehensive understanding (Takalo, 2017). Writing is one of the four basic skills that students begin to learn to communicate through writing as they begin to interact with others at the school level. Writing skills are more complicated than other language skills (Javed, et al., 2013).

Language plays a crucial role in education. It was ensured that the language as the language of communication was used as the cause of all activities in education, especially in the implementation of learning. Similarly, Indonesian language's role in making Higher Education skills. Indonesian language skills courses therefore become one of the compulsory subjects to be taken by students in the program of study of primary school teacher education. Indonesian language abilities include four facets of the ability to listen, speak, read and write. One of the reasons for this is the lack of adequate learning medium in implementing Indonesian language skills training. PowerPoint is used by users only as a media and is more text-based, so less interactive and interesting.

The Media is an interactive Adobe Flash based on multimedia. Multimedia is a mixture of various media (file format) used to communicate or deliver messages to the public in the form of text, pictures, graphics, sound, animation, video, interaction, and others that have been compiled into digital (computerized) files [Munir, 2012]. Learning Indonesian skills that require students not only to cognitively understand the material but also to be skilled in Indonesian language, the interactive multimedia plays an important role in learning. In addition, multimedia's effectiveness and benefits, making interactive multimedia helps students master the material as well as motivate them to learn. Thus messages in the form of learning materials with interactive multimedia are easier to send and accept by students. Thus, interactive multimedia can improve process quality and results in the learning of Indonesian language skills [Praheto, 2017]. Interactive can provide effective education and make the education easier. Multimedia provides the educational facilities. Students can learn new information owing to interactive education.

In education interactive multimedia is already very popular. Diverse interactive multimedia are designed to assist the learning process. The use of technology in teaching should be done after science has developed. Some of the previous studies relating to interactive multimedia were conducted by Chachil who developed interactive multimedia-based mobile Iban language learning applications [K. Chachil, 2015]. Salameh conducted a similar study through the development of an offline multimedia-based mobile-phone system for English learning. Additionally, Ampa carried out research using interactive multimedia for learning listening skills [O. Salomeh, 2011]. Furthermore, Majid-led work also develops immersive multimedia in language learning ie English. Then Zainuddin, who conducts multimedia research that creates multimedia courses to learn Arabic vocabulary [N. Zainuddin, 2016].

Learning Indonesian must be handled as well as possible, as is other learning. Unfortunately, there are still various problems in the field of Indonesian language learning, such as low-level student activities due to lack of enthusiasm or interest in attending lessons and the use of instructional media is not yet optimum. That condition leads to unsatisfactory results in 
language learning [Mardhatillah, 2017]. One solution to this problem is the provision of interactive learning multimedia that combines the simultaneous use of text, images, sounds, animations, and videos according to the learning needs of Indonesian. That solution is based on Lindstrom's opinion, [Neo Ken, 2004] it notes that multimedia offers a way to supplement teachers ' efforts to gain feedback, improve engagement and enhance student comprehension.

[Pradana,2017] claimed that teacher allegations are quite a lot nowadays. In the past, the teachers ' important task was teaching, but now the teacher also performs administrative duties, besides teaching quite hard. [Antonietti, 2006] states that multimedia learning requires teachers to have computer skills.

\section{Research Method}

\subsection{Research Setting}

This research was conducted at four higher institutions, namely IKIP PGRI Wates in Yogyakarta, Slamet Riyadi University in Surakarta, Tunas Pembangunan University in Surakarta, and Ahmad Dahlan University in Yogyakarta.

\subsection{Research Design}

This experimental research used the posttest along with a control group design. Participants were categorized or randomly placed in two groups. Researchers both conducted posttests in both groups, and the experimental group (A) was treated (Cresswell, 2014). The effectiveness test was conducted in four higher institutions, namely IKIP PGRI Wates as an experimental group by applying interactive multimedia, Slamet Riyadi University of Surakarta as a control group by applying videocribe-based media, Tunas Pembangunan of Surakarta University as a control group by applying the prize-based media, and Ahmad Dahlan University of Yogyakarta as a control group by applying the powerpoint-based media. All groups were then subjected to the posttest and calculated differences in posttest results using one-way annova and further tests to find out which group had the most significant difference.

\subsection{Population, Sample, and Sampling}

The study population consists of students of the Elementary School Teacher Education (PGSD) Study Program in the faculty of teacher training and education in Yogyakarta and Surakarta. Samples were the second semester students of IKIP PGRI Wates in Yogyakarta, Ahmad Dahlan University in Yogyakarta, Slamet Riyadi University in Surakarta, and Tunas Pembangunan University in Surakarta. They are averagely 18 years old. Total lecturers are 4 people who work full time and have work experience of around 5-10 years. Class A students are used as an experimental group, while class B students act as a control group. Each class consists of 27-31 students. The experimental class and the control class were determined through the random sampling. IKIP PGRI Wates involved class A1 (an experimental class) that applied interactive multimedia, University of Tunas Pembangunan involved class B1 (a control class) that used the media prize, Slamet Riyadi University involved class B2 (a control class) that implemented videoscribe media, and Ahmad Dahlan University (UAD) involved class B3 (a control class) that implemented the media powerpoint. 


\subsection{Data Collection Technique}

The data collection technique used Indonesian language proficiency tests that include listening ability tests, speaking ability tests, reading ability tests, and writing ability tests. Next, the four test scores are combined and averagely become the results of Indonesian language proficiency tests.

\subsection{Data Analysis Technique}

The collected data were analyzed descriptively focusing on the central trend analysis (mean, median, mode, range, standard deviation, and variance) and inferentially using a one-way ANNOVA to analyze the interactive multimedia effectiveness hypothesis. Before testing hypotheses in the form of inferential statistics, the data were tested in terms of the variance homogeneity using the lavene test. After testing the hypothesis, further tests used the tukey test to compare between the two groups.

\section{RESULT}

\subsection{Descriptive Statistics}

Data diperoleh melalui postes yang dilakukan untuk mengetahui nilai keterampilan berbahasa Indonesia setelah diterapkan multimedia interaktif serta media lain untuk pembanding. Postes yang dilakukan mencakup empat aspek keterampilan berbahasa, yaitu keterampilan menyimak, berbicara, membaca, dan menulis. Hasil postes keterampilan berbahasa Indonesia yang menggunakan empat media berbeda dapat dilihat pada tabel deskriptif statistik di bawah ini.

The research data from the post-test were used to determine the scores of Indonesian language skills after applying the interactive multimedia and other media for comparison. The post-test covered four aspects of language skills, namely listening, speaking, reading and writing skills. The results of the Indonesian language skills tests using four different media can be viewed in the statistical descriptive table below.

Table 1: The Descriptive Test of Indonesian Language Skills Tests

\begin{tabular}{|c|c|c|c|c|c|c|c|c|c|}
\hline & \multirow[t]{2}{*}{ Group } & \multirow[t]{2}{*}{$\mathbf{N}$} & \multirow[t]{2}{*}{ Mean } & \multirow[t]{2}{*}{$\begin{array}{c}\text { Std. } \\
\text { Deviation }\end{array}$} & \multirow[t]{2}{*}{ Std. Error } & \multicolumn{2}{|c|}{$\begin{array}{l}\text { 95\% Confidence } \\
\text { Interval for Mean }\end{array}$} & \multirow[t]{2}{*}{ Min. } & \multirow[t]{2}{*}{ Max. } \\
\hline & & & & & & $\begin{array}{l}\text { Lower } \\
\text { Bound }\end{array}$ & $\begin{array}{l}\text { Upper } \\
\text { Bound }\end{array}$ & & \\
\hline $\begin{array}{l}\text { IKIP PGRI } \\
\text { Wates }\end{array}$ & $\mathrm{A}_{1}$ & 30 & 78.28 & 6.76168 & 1.23451 & 75.7571 & 80.8069 & 64.32 & 93.57 \\
\hline UTP & $\mathrm{B}_{1}$ & 27 & 69.82 & 9.35841 & 1.80103 & 66.1216 & 73.5258 & 43.93 & 86.68 \\
\hline UNISRI & B2 & 30 & 64.10 & 6.83693 & 1.24825 & 61.5497 & 66.6556 & $49 \cdot 75$ & 78.04 \\
\hline UAD & $\mathrm{B}_{3}$ & 31 & 75.92 & 6.05753 & 1.08796 & 73.6965 & 78.1403 & 61.82 & 86.32 \\
\hline Total & & 118 & 72.12 & 9.11297 & .83892 & 70.4593 & 73.7822 & 43.93 & 93.57 \\
\hline
\end{tabular}

Note:

A1: IKIP PGRI Wates as an experimental group using the interactive multimedia

B1: Universitas Tunas Pembangunan (UTP) as a control group using the media prize

B2: Universitas Slamet Riyadi (UNISRI) as a control group using videoscribe media

B3: Ahmad Dahlan University (UAD) as a Control Group using the powerpoint media 
Table 1 shows the highest average score of 78.28 in the class by implementing the interactive multimedia in learning Indonesian language skills, while the lowest average score of 64.10 in the class by applying video-based media.

\subsection{Homogeneity Test Results}

The analysis of homogeneity used Lavene test, as shown in the following table.

Table 2: The Homogeneity Test of Lavene Test

\begin{tabular}{ccc}
\hline Lavene Test & Sig. & Note \\
\hline 1.914 & 0.131 & Homogenous \\
\hline
\end{tabular}

Table 2 proves that the significance value is more than 0.05 . This means that data are homogeneous.

\subsection{The Result Analysis of Experimental Difference}

The bivariate analysis at this stage investigates "the difference between experiments in terms of Indonesian language skills" using the one-way Annova test as seen in the following table.

Table 3: The Result Analysis of Experimental Difference

\begin{tabular}{ccccc}
\hline & Group & Mean \pm SD & Sig. & Note \\
\hline \multirow{3}{*}{ Post-test } & IKIP Wates & $78.28 \pm 6.76$ & \multirow{2}{*}{0.000} & $\begin{array}{c}\text { There is a } \\
\text { difference. }\end{array}$ \\
\cline { 2 - 3 } & UTP & $69.82 \pm 9.35$ & & \\
\cline { 2 - 3 } & UNISRI & $64.10 \pm 6.83$ & & \\
\cline { 2 - 3 } & UAD & $75.91 \pm 6.05$ & & \\
\hline
\end{tabular}

As Table 3 proves, there are differences in experiments in terms of Indonesian language skills in the post-test group or there are significant differences between test groups. This is evidenced by the significance value on the one-way Annova test results showing a value of 0.000 or less than 0.05 .

\subsection{Further Result Analysis}

Further tests were carried out to compare between the two groups. The comparison of the two groups used the tukey follow-up test. The results can be known, as follows.

Table 4: The Analysis of Experimental Differences between 2 Groups

\begin{tabular}{llllll}
\hline & Group & IKIP Wates & UTP & UNISRI & UAD \\
\hline \multirow{5}{*}{ Post-test } & IKIP Wates & - & 0.000 & 0.000 & 0.586 \\
\cline { 2 - 5 } & UTP & - & 0.019 & 0.010 \\
\cline { 2 - 6 } & UNISRI & & - & 0.000 \\
\cline { 2 - 6 } & UAD & & & - \\
\hline
\end{tabular}

Table 4 shows the difference between the two experimental groups, namely differences in the experiments on the results of Indonesian language skills tests in the post-test group, between IKIP Wates and UTP or vice versa. The significance value on the results of Tukey's further tests is o.ooo or less than 0.05 . In addition, there are experimental differences in the results of Indonesian language skills tests in the post-test group between IKIP Wates and UNISRI or vice versa. The significance value of the results of Tukey's further tests is 0.000 or less than 0.05 . 


\section{Discussion}

The results of Indonesian language skills tests include listening, speaking, reading and writing skills. The learning of Indonesian language skills using interactive multimedia is better than learning that of other media, namely media prize, videoscribe, and powerpoints. This is because learning using interactive multimedia is student-centered. In this sense, students' activities in the classroom increase. Multimedia is effective (Ilhan and Oruc, 2016) as it provides facilities in education particularly in learning activities. Multimedia practices are important for students to learn new information. The use of multimedia facilitates and objectifies learning because it presents technological factors to students and addresses more recipient's emotions. In a digital learning environment, multimedia offers rich learning opportunities to meet the students' needs (Kim et al, 2013). The use of multimedia integrates various elements such as audios, videos, authentic contexts and real world experiences that help language learners who have different learning styles to assimilate contents according to classroom needs. On the other hand, multimedia provides different learning facilities for students to carry out further practices on various language skills to accommodate individual needs and interests. This situation makes the learning environment more interactive, dynamic, fun, and interesting (Hashemyolia, 2015).

The effectiveness test was conducted at four higher education institutions by applying different media from each other. The four campuses consist of one experimental class and three control classes. The experimental class is IKIP PGRI Wates that uses interactive multimedia. The control class is Tunas Pembangunan University that applies prize-based media, Slamet Riyadi University uses videoscribe-based media, and Ahmad Dahlan University uses powerpoint-based media. Based on the further Tukey test, there are significant differences between the experimental classes implementing the interactive multimedia at IKIP PGRI Wates and the control classes applying videoscribe-based media at Slamet Riyadi University, and there are significant differences between the experimental classes implementing the interactive multimedia at IKIP PGRI Wates along with a control class applying prezi-based media at Tunas Pembangunan University. This significant effect shows that the students' mastery of Indonesian language skills in the experimental class is better than that of the control class applying videoscribe and prezibased media. This is because the flexibility and interactivity of multimedia is better than the videocribe and prezi-based media. Interactive multimedia is more interesting than other media containing more learning materials. Ampa (2015) states that by using interactive multimedia, students can be motivated to learn, because they can listen to audios, watch videos or view texts, animations and graphics simultaneously.

All media in both the experimental class and in the control class are computer-based media, however, the media in the control class are merely one-way for lecturers to use and can only contain a few materials. This is because there is no interactive nature on the media used in the control class, so that content-based materials will save the users' time because they do not need to have a navigation button to select the materials. In this case, interactive multimedia is very suitable for use in the learning of Indonesian language skills. It is required to master the materials theoretically and practically because interactive multimedia contains diverse elements of texts, animations, images, videos, and sounds and navigation buttons are attached to the multimedia 


\section{Conclusion}

The results show that the application of interactive multimedia is effective in learning Indonesian language skills. Students' learning outcomes in classes using interactive multimedia are better than that of the classes that apply videoscribe, prize, and powerpoint-based media. This is because interactive multimedia is more student-centered and it can be used by students both in the classroom and outside the classroom. Multimedia has advantages including loading wideranging elements in terms of the texts, videos, animations, images, and sounds. Interactive multimedia has a navigation button that allows users to choose the materials that they want to learn according to their needs. In a nutshell, interactive multimedia developed for learning Indonesian language skills is strongly suitable for the learning application.

\section{Acknowledgement}

I would like to thank the Ministry of Technology and Higher Education Research of Republic of Indonesia for its full support through the 2018 Desertation Research Doctoral grant program.

\section{References}

Ahmad, A. (2017). Application of Language Games (Catharsis) to Improve Reading Skills of Grade fourth A Students at Central Metro o1 Elementary School. EduHumaniora: Journal of Basic Education, 9/2, $75-83$.

Ampa, A. T. (2015). The Implementation of Interactive Multimedia Learning Materials in Teaching Listening Skills. English Language Teaching, 8/12, 56-62.

Brown, H. D. (2015). Teaching by principles: An interactive approach to language pedagogy. United States: Pearson Education

Brown, G. \& Yule. (1996). Discourse Analysis. Cambridge: Cambridge University Press.

Burns, A. \& Joyce, H. (1997). Focus on Speaking. Sydney: National Center for English Language Teaching and Research.

Caspersz, Donella and Stasinska, Ania. (2015). Can we teach effective listening? An exploratory study. Journal of University Teaching E Learning Practice, 12/ 4.

Crawley, S. J. \& Mountain, L. (1995). Strategies for Guiding Content Reading. Boston: Allyn and Bacon.

Daryanto. (2013). Effective Learning Innovation. Bandung: Yrma Widya.

Gilakjani, Abbas Pourhosein \& Sabouri, Banou. (2016). How Can Students Improve Their Reading Comprehension Skill?. Journal of Studies in Education, 6/ 2.

Gilakjani, P. A. \& Sabouri, N. B. (2016). Learners' Listening Comprehension Difficulties in English Language Learning: A Literature Review. English Language Teaching, 9/6, 123-133.

Hamouda, A. (2013). An Investigation of Listening Comprehension Problems Encountered by Saudi Students in the EL Listening Classroom. International Journal of Academic Research in Progressive Education and Development, 2/2, 113-155. 
Hashemyolia, Shayeshteh; Ayub, Ahmad Fauzi Mohd; Moharrer, Zahra. 2015. The Effectiveness of Multimedia Language Courseware on Secondary School Students' Motivation for learning English. Mediterranean Journal of Social Sciences, 6/ 6.

Ilhan, G. O. \& Oruc, S. (2016). Effect of The Use of Multimedia on Students' Performance: A Case Study of Social Studies Class. Academic Journals: Educational Research and Reviews, 11/8, 877-882.

Javed, Muhammad; Juan, Wu Xiao; \& Nazli, Saima. 2013. A Study of Students' Assessment in Writing Skills of the English Language. International Journal of Instruction, 6/ 2.

Kim, D.; Kim, D. J. \& Whang, W. H. (2013). Cognitive Synergy in Multimedia Learning. International Education Studies, 6/4, 76-84.

Lakilaf, N. S. \& Suarjana, I. M. (2017). Application of Think-Pair-Share Learning Model to Improve Writing Skills of second-grade Students at Public Elementary school 3 Banjar Jawa. Elementary School Scientific Journal, 1/4, 84-287.

Leong, Lai Mei \& Ahmadi, Seyedeh Masoumeh. 2017. An Analysis of Factors Influencing Learners' English Speaking Skill. International Journal of Research in English Education, 2/ 1.

Mayer, Richard. E. (2011). Multimedia Learning. United Kingdom: Cambridge University Press.

Munir. (2012). Multimedia: Concepts \& Applications in Education. Bandung: Alfabeta

Orsdemir, E. \& Yilmazer, M. O. (2016). Note Taking in The EFL Listening Classroom: an Action Research. International Journal of Language Academy, 4/2, 208-216.

Patel, C. (2013). Use of Multimedia Technology in Teaching and Learning communication skill": An Analysis. International Journal of Advancements in Research $\mathcal{E}$ Technology, 2/7, 116-123.

Philips. (1997). The Develophe's Handbook to Interactive Multimedia: a Practical Guide for Educational Applications. London: Kogan page limited.

Pu'at. (2017). Efforts to Improve Intensive Reading Skills by Using Class V Cooperative Learning in Public Elementary School 11 Tebat Karai. PGSD Bengkulu University Journal: Primary School Scientific Education Journal, 10/2, 107-113.

Reddi, U. V. \& Sanjaya M. (2003). Educational Multimedia- A Handbook for Teacher-Developers. New Delhi: The Commonwealth of Learning Commonwealth Educational - Media Centre for Asia.

Ruomei, F. \& Feng, M. (2012). The Use of Multimedia in Chinese Language Teaching at Binus University. HUMANIORA, 3/2, 392-399.

Takaloo, Nahid Mohseni \& Ahmadi, Mohammad Reza. (2017). The Effect of Learners' Motivation on Their Reading Comprehension Skill: A Literature Review. International Journal of Research in English Education, 2/3.

Tuan, Nguyen Hoang \& Mai, Tran Ngoc. 2015. Factors Affecting Students' Speaking Performance at Le Thanh Hien High School. Asian Journal of Educational Research, 3/ 2.

Vaughan, T. (2014). Multimedia: Making It Work: 9th Edition. New York : McGraw-Hill.

Wicaksono, A.; Ekowati, D. W. \& Yuliati. (2019). Improved Poetry Writing Skills with Observing Models, Imitation, Modifications Using Image Media in fourth-grade student Purwantoro 2 Malang. Taman Cendekia Journal, 3/1, 307-313.

Ziden, A. A. \& Rahman, M. F. A. (2013). The Effectiveness of Web-Based Multimedia Applications Simulation in Teaching and Learning. International Journal of Instruction, 6/2, 211-222.

Zuhari, A. W.; Djumhana, N. \& Mulyasari, E. (2018). The application of Reading Guide Method to Improve Reading Ability of Public Elementary School four grade Students. Journal of Elementary School Teacher Education, 3/2, 11-21. 
Munir. (2012). Multimedia: Konsep \& Aplikasi dalam Pendidikan. Bandung: Alfabeta.

B. E. Praheto, Andayani, M. Rohmadi, and N. E. Wardani. (2017). Peran Multimedia Interaktif Dalam Pembelajaran Keterampilan Berbahasa Indonesia Di Pgsd. Proceedings, pp. 173-177.

K. Chachil, R. M. Rias, A. Engkamat, and A. Sarkawi. (2015). Interactive multimedia-based mobile application for learning iban language. J. Teknol., vol. 75, no. 3, pp. 41-46.

O. Salomeh. (2011). A multimedia offline cellphone system for English language learning. Int. Arab J. Etechnology, pp, vol. 2, no. 1 SRC-GoogleScholar FG-o, pp. 44-48.

N. Zainuddin and M. S. Sahrir. (2016). Multimedia Courseware for Teaching Arabic Vocabulary: Let's Learn from the Experts. Univers. J. Educ. Res., vol. 4, no. 5, pp. 1167-1172.

Mardhatillah dan Fahreza, F. (2017). Pengembangan media pembelajaran bahasa indonesia berbasis macromedia flash professional 8 untuk Kelas V SDN kasik putih kecamatan samadua kabupaten aceh selatan. Jurnal Visipena, 8(2): 262-79. Available: http://visipena.stkipgetsempena.ac.id/home/article/download/178/167.

Neo Ken, T. K. and Neo, M. (2004). Classroom innovation, Engaging students in interactive multimedia learning. Campus-Wide Information Systems, 21(3): 118-24. Available: https://doi.org/10.1108/10650740410544018.

Pradana, D. W. (2017). Budaya engagement, Pengaruhnya terhadap keunggulan kompetitif pada sekolah swasta di semarang. Ekspektra. Jurnal Bisnis Dan Manajemen, 1: 173-87.

Antonietti, A. and Giorgetti, M. (2006). Teachers' beliefs about learning from multimedia. Computers in Human Behavior. 